\title{
Using the CLB in WorkLINC
}

\author{
Audrey Beaulne \\ Immigrants Working Centre
}

\begin{abstract}
Striving for greater English proficiency and securing a job are common goals of newcomers to Canada. For newcomers in the Language Instruction for Newcomers to Canada (LINC) program, the Canadian Language Benchmarks (CLB)/Niveaux de competence linguistique canadiens (NCLC) provide an indicator of their abilities and progress in their language acquisition. The CLB have become the backbone of WorkLINC, an industry-specific work readiness program. They anchor curriculum, Portfolio-Based Language Assessment (PBLA) real-world tasks, and classroom activities. WorkLINC participants develop their vocabulary, soft skills, workplace safety knowledge, and get employment support. Instructors have shared the CLB with employers and community partners to increase comprehension of newcomers' language levels. Though there are challenges meeting the diverse needs in multi-level cohorts, engaging learners about the purpose of classroom tasks and understanding the CLB competency areas in which they need development enables them to focus on achievable goals directly related to their employment aspirations.
\end{abstract}

\section{Résumé}

S'efforcer de mieux maîtriser l'anglais et se trouver un emploi sont des buts communs des nouveaux arrivants au Canada. Pour les nouveaux arrivants au programme Cours de langue pour les immigrants au Canada (CLIC), les Niveaux de compétence linguistique canadiens (NCLC) fournissent un indicateur de leurs capacités et de leurs progrès dans leur acquisition linguistique. Les NCLC sont devenus le pilier de WorkLINC, un programme de préparation au marché du travail propre à l'industrie. Ils soutiennent le curriculum, les tâches du monde réel de l'évaluation linguistique basée sur le portfolio (ELBP) et les activités en classe. Les participants à WorkLINC perfectionnent leur vocabulaire, leurs compétences non techniques et leurs connaissances de la sécurité au travail, et obtiennent du soutien à l'emploi. Les instructeurs ont partagé les NCLC avec des employeurs et des partenaires communautaires afin d'accroître la compréhension des niveaux linguistiques des nouveaux arrivants. Bien qu'il y ait des défis à relever pour répondre aux divers besoins de cohortes multiniveaux, le fait d'intéresser les apprenants au but des tâches en classe et de leur faire comprendre les domaines de compétence des NCLC dans lesquels ils ont besoin de perfectionnement leur permet de se concentrer sur les buts réalisables directement liés à leurs aspirations en matière d'emploi. 


\section{Using the CLB in WorkLINC}

As the national standard in Canada for adult English language learners in the Language Instruction for Newcomers to Canada (LINC) program, the Canadian Language Benchmarks (CLB) provide a framework for newcomers to gauge their needs and progress not only in their language acquisition but also their skills development as they prepare for the workplace. The WorkLINC program at the Immigrants Working Centre (IWC) in Hamilton, Ontario, offers intensive, industry-specific work readiness classes for learners looking for employment. The CLB, designed for broad application in study, community, and workplace contexts, have been the foundation of curriculum development unique to WorkLINC and the implementation of Portfolio Based Language Assessment (PBLA) within the program. This ensures learners can move through their language learning and work towards their employment goals simultaneously. This article describes the evolution of WorkLINC, how the CLB are used in its program design and classroom practice, and some of the challenges the instructors have encountered in delivering the program.

\section{The WorkLINC Program}

Initially started in 2016 to meet the needs of low-level, employment-seeking newcomers to Hamilton, WorkLINC has become a permanent part of IWC's LINC program. WorkLINC offers a two-pronged approach to learners becoming employed: classes for English language development, including safety certifications, plus individual support from IWC's employment counsellors. IWC has offered WorkLINC cohorts in language preparation for employment in transportation (licensing for school bus drivers, heavy equipment operators, and for truck drivers: Ontario Class AZ and Class DZ licenses with air brake endorsement), welding and industrial painting, as well as introductions to the industries of construction, manufacturing and production, and food hospitality. Learners attend full-time classes which typically run for six to eight weeks. WorkLINC focuses on industry-specific vocabulary building, the practical application of English for communication on the job, developing learners' soft skills, and increasing their understanding of the role that workplace safety has in the Canadian workplace. For each WorkLINC cohort, training and certification is included in Globally Harmonized System Workplace Hazardous Materials Information System (GHS-WHMIS), Worker Health and Safety Awareness, and, depending on the cohort, Working at Heights or Safe Food Handling, delivered by a community partner organization. IWC has partnered with a driver training centre, an industrial painter training centre, Mohawk College's City School, and Ontario Works to offer eligible WorkLINC participants taking transportation, industrial painter, or welding cohorts a second phase to their preparation for the workplace, with the goal of learners gaining employment upon successful completion of their training.

\section{The Evolution of WorkLINC}

When cohorts first began, WorkLINC did not have a specific CLB requirement for admission; course material and tests were focussed on occupation-related vocabulary and basic safety. However, with some cohorts consisting of learners from pre-CLB through 
CLB 6, it was a challenging undertaking to meet the needs of everyone, and content was generalized. WorkLINC was also not required to incorporate PBLA practices initially, and for learners already in the LINC program in Hamilton, at IWC or another LINC provider, attending a cohort meant they were unable to complete any benchmarked artefacts.

Graduates who did not immediately get a job often returned to LINC classes, without CLBbased evidence of their language learning from their weeks in WorkLINC. The employment and LINC teams at IWC noted the frustrations of lower-level learners who were motivated to get a job and eagerly participated in WorkLINC, but then faced difficulties because the language practice was not always CLB-appropriate; they still needed more in-class time to develop their skills. Considering the backgrounds and needs of newcomer learners and tailoring instruction to certain jobs is vital to building an ideal course for employment-seeking language learners (Ghadi et al., 2019, pp.83-84). WorkLINC needed to be more focussed in its delivery of workplace language instruction and to better document learners' progress.

To address this, in January, 2018, IWC set CLB 3 as the minimum requirement for admission to WorkLINC, and a resource teacher was employed to work with and support the classroom instructor with implementing PBLA and administering assessments. The resource teacher was also tasked with developing curricula and modules for existing and new cohorts, curating classroom resources, creating original activities, and incorporating non-benchmarked industry and certification training material into CLB-appropriate lessons. Although the requirement for entrance to WorkLINC is CLB 3 or higher, and the cohorts are designed for up to CLB 5, exceptions continue to be made occasionally for lower-level (CLB 1 and 2) or higher-level (CLB 6 and up) learners depending on their past experience in the industry of the cohort. Learners may also have literacy needs and require more support with reading and writing tasks such as understanding and filling in forms, or reading and following multi-step safe-use instructions on a product used in the workplace. To this end, collaborating with each learner to determine their language goals during their participation in WorkLINC not only helps guide them to become more autonomous in their learning, it also helps the instructor focus lessons (Centre for Canadian Language Benchmarks [CCLB], 2019).

\section{The Canadian Language Benchmarks in Practice}

The CLB describes a learner's communicative ability to perform real-world tasks. It presents language abilities within four main competency areas - listening, speaking, reading, and writing - and describes the criteria essential for learners' progression through different competency levels. The benchmarks are, by design, learner-centred and taskbased, which fits well with the objectives of WorkLINC learners; i.e., to improve their English proficiency and function successfully in the Canadian workplace. The descriptors representing each benchmark were therefore used to develop course curricula and learner practice materials (CCLB, 2012). 


\section{Using the CLB for WorkLINC Curriculum Development}

The resource teacher collaborated with the classroom instructor in the development of WorkLINC curriculum. Using backward design, they decided which real-world tasks would comprise the assessments for each cohort by first considering the desired outcomes (Wiggins \& McTighe, 2006). Compared to typical Stage I LINC programs, cohorts are short and intensive; importance is placed on competency areas which the majority of learners would benefit from both for their general communication and workplace safetyrelated needs. For example, it was determined that two listening and speaking competency areas (Comprehending and Giving Instructions, and Getting Things Done) were relevant to all cohorts.

Based on these key competency areas, assessment tools and skill-building lessons were developed. Multi-level rubrics for real-world task assessments were created by the resource teacher. Then, the classroom instructor organized focussed lessons, in consultation with the resource teacher, aiming to maximize learners' practice of workplace-specific language with skill-building activities for the real-world tasks. Skill-building activities were developed to be practical, applicable in a variety of workplace scenarios, and relevant to the learners in the cohort. In the food hospitality cohort, for example, the activities were intended to develop skills to adequately perform in a giving/following instructions roleplay, to develop food vocabulary, adjectives for foods and containers and measurements (metric and imperial units), as well as verbs for the preparation and safe handling of food. Practice and in-class discussion of correct use of courtesy forms and structures were also incorporated. In the assessment role-plays, learners were able to follow and give instructions in situations typical to the many jobs in a food hospitality workplace: a cook instructing a new kitchen helper, or a fast-food worker listening to a co-worker instruct them how to prepare a sandwich.

On the first day of a new cohort, learners participate in a brief one-on-one interview to discuss their language goals and needs. Referencing the CLB in goal-setting with learners provides a means of self-assessment; thinking about their own skills and strengths encourages learners' responsibility for their learning and builds confidence (Senior, 2017, p. 81). Often, learners say they need to improve their social communication skills, and some tell anecdotes of communication issues they have had in class, at work, or in the community. Drawing on self-identified student needs, the WorkLINC instructors intentionally build lessons based on students' self-identified needs which integrate explicit instruction on sociolinguistic knowledge (e.g., using and understanding non-verbal communication) and strategic competence (e.g., asking for clarification or repeating back), along with the criteria of the competency areas (CCLB, 2012). As Hajer (2012) notes in the $C L B$ Support Kit, these elements support the successful settlement of newcomers:

"pragmatic knowledge plays a crucial role in determining newcomers' integration" (p. 71). For instance, in the food hospitality cohort, pragmatic knowledge is woven into classroom activities by introducing and assessing the use of soft skills needed for working with coworkers and customers in kitchens, cafeterias, banquet centres, and restaurants. Learners from CLB 2 through CLB 5 are assigned the real-world task assessment of listening and 
responding to a request for assistance from a co-worker, supervisor, or customer (Getting Things Done competency area). They are evaluated using CLB-appropriate criteria based on sociolinguistic knowledge, such as seeking clarification. Learners have responded positively to this practice and the assessment, seeing the difference in the quality of their communication when they use these skills successfully. Supporting learners in achieving their language goals by aligning student needs with CLB-based curriculum design is a main focus of WorkLINC.

\section{Using the CLB with Training Material}

For some cohorts, IWC partners with organizations for a second phase of training, such as the AZ truck driver cohort, where learners continue on after completing WorkLINC to attend a local commercial drivers training centre. Therefore, WorkLINC lessons and assessments were designed to reflect the tasks learners would be expected to successfully complete in this training and to succeed in potential on-the-job situations. For example, truck drivers need to understand and fill in vehicle inspection reports, which have specific formats and language. WorkLINC's AZ drivers cohorts are comprised of learners with years of international truck driving experience, as well as those who have never driven a truck before. Since learners can range from CLB 3 to 6 across the four skills, multi-level reading comprehension and writing activities for Competency Area III, Getting Things Done, have been incorporated; learners practice reading completed report forms and how to fill in inspection reports.

In another example, the language preparation for welding cohort in 2019 was a partnership between WorkLINC and Mohawk College's City School which offered a hands-on introduction to welding course. The City School course was taught by a professional welder, not a LINC instructor, which meant the class needed to understand instructions, requests, and warnings that were not differentiated for a multi-level class of English learners. Some learners were experienced welders but had never worked in Canada and their English level was low (CLB 3), while others who were higher-level (CLB 6) were trying welding for the first time. WorkLINC lessons prepared learners for their City School training with skill-building activities focussing on technical vocabulary for welding materials, equipment, and relevant adjectives and adverbs. Learners were given speaking and listening assessments with scenarios such as instructing a co-worker on how to fix a weld defect.

To ensure learners were as prepared as possible for their continued training, the WorkLINC resource teacher benchmarked and cross-referenced industry training material for truck drivers and industrial painters. Material provided by the training centres is not created for English language learners and is written at a much higher level than WorkLINC learners' reading abilities. The WorkLINC resource teacher discussed with IWC's employment team and the training provider which areas of the training they felt newcomers would most benefit from in pre-training practice. Prior to the start of the first cohort, the resource teacher and classroom instructor consulted the class list, to consider the proficiency levels across all four skills of the participants, and identify whether they had any industry experience. The instructors used training material, such as a truck driver's handbook, to develop vocabulary lists and skill-building activities based on authentic 
workplace situations. The Features of Communication pages in the CLB, which provide a comparison of the benchmarks across Stage I, were used to create multi-level activities for practice (CCLB, 2012).

To illustrate, in the AZ driver cohort, learners practice prepositions of location and movement and the imperative in a jigsaw activity to give instructions for proper vehicle handling, working on the ways of backing up a tractor and trailer (straight backing, alley dock and offset backing). To begin the activity, the classroom instructor teaches essential pre-reading vocabulary, then groups learners according to their reading CLB and gives them level-appropriate text. For the sharing portion of the activity, learners are put into mixed-level groups, allowing learners to practice the language as a whole class. In this way, learners are able to work on their language skills and their employment goals of driving a truck prior to doing the actual driving during their course at the driver training centre. While this process of benchmarking training material takes time and requires the resource teacher and classroom instructor to become experts in the training material for the cohort, not just the CLB, this expertise is essential to WorkLINC learners' preparedness. By including practice and assessment of specific skills that learners need for a job and training-related tasks, along with the focus on workplace communication, learners become well-equipped for their next step post-WorkLINC.

\section{Using the Can Do Statements for Employment}

The Can Do Statements for Employment is a useful document not only for the WorkLINC classroom instructor and resource teacher, but also to be shared with other training providers and potential employers (CCLB, 2016). In WorkLINC, learners can use the document for goal-setting with their instructor to better understand their workplace language abilities. These simplified statements of the CLB competencies pertaining to employment (CLB levels 4 to 10) are comprised of examples of a learner's English language abilities from three perspectives - the job-seeking newcomer, the employment counsellor, and the newcomer-hiring employer. The statements pair listening and speaking skills, and reading and writing skills to give examples of workplace language tasks. The document is user-friendly, especially for employers with little to no familiarity with the CLB. However, there are gaps in the document's in-class applications and its accessibility for employers and non-LINC training providers.

One significant challenge is that low-level learners' communicative needs and abilities are not reflected in the Can Do Statements for Employment. Many WorkLINC learners have not yet achieved CLB 4, the level at which the Can Do Statements for Employment begin. Some of these lower-level WorkLINC participants have attended the program while working. They expressed a desire to get better jobs in the future and shared many stories about the barriers and problems they have faced because of their low level of English. It is linguistically and socially complex to "understand the 'unwritten rules' of Canadian work culture, expected workplace behaviour, in order to retain a job and succeed as well" (Bartel, 2018, p.81). Lower-level learners in particular benefit from continued jobrelated practice of their language skills. Including "can do" statements for CLB 3 and below in the Can Do Statements for Employment would allow these learners to do self- 
assessments and have a shared frame of reference about workplace language abilities with their employers.

Another challenge is that many community partner organizations are not aware of the CLB or the Can Do Statements for Employment. In workplace safety certification training sessions, such as Working at Heights, or GHS-WHMIS, which are integrated into the WorkLINC program but delivered by a community partner organization, the trainers' unfamiliarity with the CLB as well as the diverse needs in multi-level cohorts creates issues for lower-level learners when sessions are delivered; they require extra support to participate and understand. The WorkLINC instructor and resource teacher have discussed the lower-level learners' needs with the trainers and their organization and made reference to the Can Do Statements for Employment. The trainers are willing to support the learners by modifying their oral presentation of the content and allowing for peer translation within the session. Nevertheless, the format of the training and the texts, developed to be delivered to native English speakers, has changed minimally. To address this gap, the classroom instructor teaches preparation lessons for the training sessions to cohorts with a majority of learners lower than CLB 4, focussing on essential vocabulary and the basic concepts.

Increased awareness of the CLB, as supported by the Can Do Statements for Employment, would benefit employers and workplace safety certification trainers. They would gain better understanding of the language abilities and limitations of learners with lower proficiency levels and how to assist them. In summary, while it is a useful tool for learners, trainers, and employers who access it, the Can Do Statements for Employment needs to be more inclusive of all CLB Stage I levels and more broadly distributed.

\section{Conclusion}

By using the CLB as the foundation for WorkLINC's curricula, activities for skillbuilding, and PBLA tasks for assessment, learners are able to participate in collaborative programs where they can increase their English language skills and take steps towards their employment goals. Indeed, the CLB "supports the changing needs of immigration in Canada within a rigorous and reliable framework" (Senior, 2017, p.87). While WorkLINC provides a valuable foundation of language as well as employment supports for many learners, and IWC continues reaching out to employers and trainers to facilitate better knowledge of the CLB, there is a need for greater cross-industry communication about the CLB. Furthermore, there is a need for openness to and support for adaptation of on-the-job and training session language, particularly for those working with Stage I learners. Increasing efforts to familiarize community training providers and employers with the Canadian Language Benchmarks will improve newcomers' experiences in their job search, language learning, and ultimate success in the Canadian workplace.

Correspondence should be addressed to Audrey Beaulne.

Email: beaulneam@gmail.com

\section{References}

Bartel, J. (2018). Teaching soft skills for employability. TESL Canada Journal, 35(1), 7892. https://teslcanadajournal.ca/tesl/index.php/tesl/article/view/1297 
Centre for Canadian Language Benchmarks (CCLB). (2012). Canadian Language Benchmarks: English as a Second Language for Adults.

https://www.canada.ca/content/dam/ircc/migration/ircc/english/pdf/pub/languagebenchmarks.pdf

Centre for Canadian Language Benchmarks (CCLB). (2016). Can Do Statements for Employment. https://www.language.ca/product/can-do-statements-for-employmentpdf-e/

Centre for Canadian Language Benchmarks (CCLB). (2019). PBLA: Practice guidelines. https://pblapg.language.ca/

Ghadi, N., Massing, C., Kikulwe, D., \& Giesbrecht, C. (2019). Language and Identity Development Among Syrian Adult Refugees in Canada: A Bourdieusian Analysis. Journal of Contemporary Issues in Education, 14(1), 71-88.

Hajer, A. (2012). CLB support kit. Ottawa, ON: Centre for Canadian Language Benchmarks. Centre for Canadian Language Benchmarks (CCLB). https://www.language.ca/product/clb-support-kit-pdf-e/

Senior, A. (2017). Teaching and assessment: Using the CLB in a range of contexts under the stewardship of the centre for Canadian Language Benchmarks. Language is the Key, 71. http://library.oapen.org/bitstream/id/4d903a09-4731-4166-ad6a5885691bba74/631397.pdf\#page $=74$

Wiggins, G. \& McTighe, J. (2005). Understanding by design (2nd ed.). Pearson. 